\title{
Hospital-Health Psychology, Human Development and Interdisciplinarity: Research in the interface between Psychology and Health
}

Rodrigo da Silva Maia. Universidade Federal do Ceará

Thaiza Teixeira Xavier Nobre. Universidade Federal do Rio Grande do Norte Gilson de Vasconcelos Torres. Universidade Federal do Rio Grande do Norte Eulália Maria Chaves Maia. Universidade Federal do Rio Grande do Norte

\begin{abstract}
This theoretical article aims to characterize the interface between psychology and studies on the health-disease process, especially in the field of Health Psychology, with human development and interdisciplinarity as a background to these investigations. To that end, the study revisited the history of these two fields of psychology (health and human development), and the introduction of interdisciplinarity in human science research. Next, we present the main methods used in health psychology research. It is concluded that despite the various epistemological, methodological and paradigm shifts that coexist in the human sciences, much remains to be done to effectively implement a knowledge construction and research framework that addresses the complexity of the health-disease process.
\end{abstract}

Keywords: health psychology; human development; interdisciplinarity.

\section{Resumo}

Psicologia da Saúde Hospitalar, Desenvolvimento Humano e Interdisciplinaridade: pesquisa na Interface entre Psicologia e Saúde. Este artigo teórico pretende caracterizar a interface das pesquisas entre a psicologia e os estudos sobre o processo saúde-doença, notadamente, no campo da Psicologia da Saúde-Hospitalar, tendo como transfundo destas investigações o desenvolvimento humano e a interdisciplinaridade. Para tanto, o estudo revisitou a história destes dois campos da psicologia: da saúde hospitalar e do desenvolvimento humano, e a introdução do tema da interdisciplinaridade nas pesquisas em ciências humanas. Em seguida, apresentamos os principais métodos de investigação utilizados na pesquisa em psicologia da saúde-hospitalar. Conclui-se que apesar das diversas mudanças epistemológicas, metodológicas e paradigmáticas que coexistem nas ciências humanas, ainda há muito o que se construir para implementar efetivamente uma perspectiva de construção de conhecimento e de pesquisa que deem conta da complexidade do processo saúde-doença.

Palavras-chave: psicologia da saúde; desenvolvimento humano; interdisciplinaridade.

\section{Resumen}

Psicología de la salud hospitalaria, Desarrollo Humano e Interdisciplinariedad: Práctica de la Investigación en la Interfaz Psicología y Salud. Este artículo teórico tiene como objetivo caracterizar las interfaces de investigación entre la psicología y los estudios sobre o proceso salud-enfermedad, especialmente en el campo de la psicología de la salud, teniendo como antecedentes de estas investigaciones el desarrollo humano y la interdisciplinariedad. Para ello, el estudio revisó la historia de estos dos campos de la psicología: la salud y el desarrollo humano, y la introducción del tema de la interdisciplinariedad en la investigación en ciencias humanas. A continuación, presentamos los principales métodos de investigación utilizados en la investigación de la psicología de la salud. Se concluye que apesar de los diversos cambios epistemológicos, metodológicos y paradigmáticos que coexisten en las ciencias humanas, todavía hay mucho que construir para implementar efectivamente una perspectiva de construcción de conocimiento e investigación que explique la complejidad del proceso de salud-enfermedad.

Palabras clave: psicología de la salud; desarrollo humano; interdisciplinariedad. 
This paper aims to discuss, from a theoretical-practical perspective, the interface between psychology and studies on the health-disease process, with the human development process as background to the research. Thus, we divided the material to historically and conceptually present the epistemic fields of hospital-health psychology and human development psychology. Next, the role of interdisciplinarity in the development of the theoretical-methodological framework of these two fields of psychological knowledge as a science and profession is examined, in order to discuss the research methods applied, using the Psychology and Health Study Group (GEPS) of the Federal University of Rio Grande do Norte as reference. As such, the aim of the present study was to characterize the current research paradigms between psychology and studies on the health-disease process, notably in the field of Hospital-Health Psychology, with human development and interdisciplinarity as a background to these investigations.

\section{Hospital-Health Psychology: Creation process}

Different terms and nomenclatures are used to indicate the area of operation of psychology in hospitals. We use the nomenclature Hospital-Health Psychology since these two fields are indissociable in terms of knowledge production, interventions and applied research. We observed that this is a historically consolidated area of operation, underscoring interventions and the definitions of the area and the techniques used.

Castro and Bornholdt (2004) discuss the main interventions and divergences between Hospital Psychology and Health Psychology. Unlike the rest of the world, in Brazil the former emerged by introducing psychology into the hospital setting. This field produces knowledge and practices, and seeks to understand how biological or organic factors, and psychological elements such as behavior, cognition, emotions, feelings and social aspects influence the health-disease process, in terms of illness and hospitalization.

Psychology was introduced into hospitals in most of the world in the 1950s and 60s to treat psychic suffering, especially to cope with post-war sequelae, which significantly affected the world's population. The practice of psychology during this period was strongly influenced by the biomedical health-disease model, where disease is understood as something purely biological and hospital work aims at curing the disorder. In this respect, psychological interventions aim to alleviate pain, suffering or psychological disorders (Azevedo \& Crepaldi, 2016; Castro \& Bornholdt, 2004).

In Brazil, psychology was implemented in hospitals during the same period because the country's policies, actions and health programs were hospital-centered, based on a model that prioritized tertiary health care. Between 1952 and 1956, the psychologists Mathilde Neder and Aidyl Pérez-Ramos began working at the Hospital das Clinicas of the University of São Paulo (HC-USP), promoting the psychological monitoring of hospitalized children and their families (Azevedo \& Crepaldi, 2016).

The history of Brazilian psychology as a science and profession shows that the introduction of psychology, which occurred before its professionalization, marked the start of Hospital Psychology in Brazil. The issue of child hospitalization was characterized as a relevant area for psychologists to address in hospitals. This contributed significantly to the development of scientific investigations, which revealed a close relationship with theories and studies regarding the Psychology of Human Development (Alves, Santos, Ferreira, Costa, \& Costa, 2017; Azevedo \& Crepaldi, 2016; Carvalho, Souza, Rosa, \& Gomes, 2011).

However, Health Psychology was consolidated in the 1970s, a period marked by paradigm shifts in the concept of health. At the time, there was an attempt to supersede the disease-centered biomedical model, with the health field attempting to implement a holistic, comprehensive and systemic health-disease model to replace the existing one. In 1978, it was officially considered a field of research and application by the American Psychological Association (APA) (Azevedo \& Crepaldi, 2016).

Its growth in Latin American, as a theoretical and practical field, occurred in the 1980s and 90s. In Brazil in particular, with the 1988 Constitution and founding of the National Health System (SUS), psychologists were included in public health services. Activities center on patient care, the family and community, in order to overcome the body-mind dualism used by the biomedical paradigm, institute a systemic holistic understanding of the health-disease process and promote health, in a biopsychosocial perspective (Oliveira, 2011).

It is undeniable that including psychologists in hospitals provides a strategic opportunity for health psychology to manifest itself (Figure 1) through psychological interventions in an institution in which patients are suffering from illness and hospitalization. Thus, the profession focuses on providing tertiary healthcare, delimiting a physical space as a field to operate in, accompanied by a number of intervention possibilities (Azevedo \& Crepaldi, 2016). 


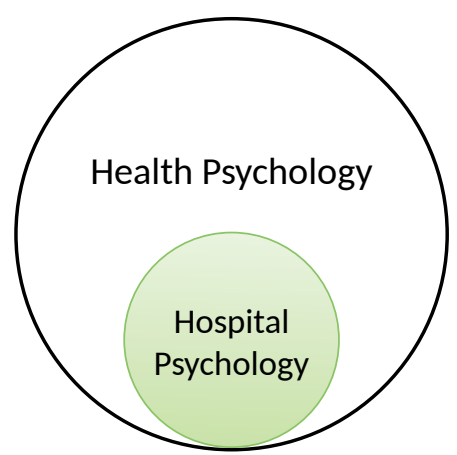

Figure 1. Overlap between Health Psychology and Hospital Psychology.

However, although Hospital Psychology is considered a Brazilian specialty, a title awarded by the Federal Psychology Council (FPC), many authors argue that the term seems inappropriate because it belongs to a framework that uses the setting to delimit the area of activities, and does not prioritize those developed in this field (Alves et al., Azevedo \& Crepaldi, 2016; 2017; Silva, Tonetto \& Gomes, 2006; Yamamoto, Trindade, $\&$ Fernandes, 2002).

With respect to research, knowledge production and techniques, there are a significant number of national and international studies that discuss three main areas: definitions of the area (what it is, the differences from other fields, professional identity, etc.), reports of experiences and psychological interventions in the hospital-health context (Alves et al., 2017; Azevedo \& Crepaldi, 2016; Reis et al., 2016). In terms of the methodological focus of the studies developed, which go against the tide of the health field as a whole, dominated by positivist quantitative research, studies in hospital-health psychology are characterized by qualitative methodologies. Studies that investigated the "experiences" and "feelings" of the disease or hospitalization process predominated (Biagi-Borges, Tonon, Scorsolini-Comin, \& Peres, 2015).

This seems to be related to the belief that the way individuals subjectively interpret their disease or suffering influences how they will address their health. As such, this methodological design is used in an attempt to understand how essentially subjective phenomena guide individuals through their health experience (Biagi-Borges et al., 2015).

On the other hand, in quantitative studies, cross-sectional designs and correlational objectives, aimed at testing a particular hypothesis, predominate. However, this method is weak because it merely provides a momentary "picture" of the phenomenon under study and how it manifests itself, lacking in-depth analysis and understanding of the issue (Biagi-Borges et al., 2015; Vizzoto \& Cressoni-Gomes, 2005).

\section{Psychology of Human Development: Trajectory to complexity}

Human development is understood as the process of transformations and stabilities that occur from conception to the end of their life. The psychology of human development, in turn, is characterized as a science dedicated to the systematic study of these transformations, changes and biopsychosocial stabilities that permeate the entire process. This science arises from the theoretical contributions of psychology, but is also influenced by other fields of knowledge, such as sociology, anthropology, physiology, genetics, and neuroscience, among others, suggesting an interdisciplinary nature (Marinho-Araújo, 2006).

According to Mota (2005), this science emerged with the publication of "The mind of the child" by the physiologist William T. Preyer in 1882, considered the birth of the science of human development, although scientific societies that investigated the characteristics of the vital cycle existed before this period (Mota, 2005).

The first thinkers that discussed human development issues from a psychological perspective date from the late $19^{\text {th }}$ to the first decades of the $20^{\text {th }}$ century. However, we underscore the importance of the theories of John Locke, Jean J. Rousseau and Immanuel Kant, philosophers from the $17^{\text {th }}$ and $18^{\text {th }}$ centuries, who conceived ideas related to self that influenced the science of human development (Mota, 2005; 2010). The proposals and reflections of these authors, as well as other publications on the issue, influenced the main theories of developmental psychology in the early $20^{\text {th }}$ century. During this period, two groups of theoretical models emerged in an attempt to explain human development: theories based on the mechanistic model and tenets of its organicist counterpart (Mota, 2005; 2010).

The human development theories based on mechanistic principles, which were influenced by Locke and his belief that man is shaped by his environment, focus on investigating human development phenomena that can be measured and quantified. Organicist theories, influenced by the ideas of Rousseau and Kant, which defended the existence of characteristics innate to the development of individuals and valued the universal processes present in typical development, underscoring the existence of internal processes and suggesting that human development occurs in a series of evolutionary stages (Mota, 2010).

Despite these differences, until the mid $20^{\text {th }}$ century the theories based on both models sought to establish 
parameters or specific normative patterns that could explain what, how and why changes and/or stability occurred throughout the vital cycle. Classic examples of theories based on these paradigms are behaviorist and learning theories, influenced by the mechanistic model, the Freudian and Ericksonian theories of psychosexual and psychosocial development, respectively, and Piaget's theory of cognitive development, grounded in organicist principles.

Studies and articles on the science of human development focused mainly on children and adolescents. After the Second World War, systematic studies were conducted with adults and the elderly (Neri, 2004). Another peculiar characteristic of this science is its method. The following primary investigative techniques were used to produce human development knowledge: observations, interviews and questionnaires, suggesting that the birth of this science was influenced by positivist epistemology, which gave studies in the area a predominantly quantitative nature (Mota, 2005; 2010).

\section{Interdisciplinarity is the new paradigm in the study of human development and health psychology}

The second half of the $20^{\text {th }}$ century was marked by a paradigm crisis in science, with repercussions $s$ in human sciences, particularly human development studies and the field of hospital-health psychology. This stemmed from intense criticism of pure scientism, touted by the hard sciences and proposals of the complexity theory, whose chief proponent, Edgar Morin, contributed to introducing complex systemic thought into discussions on the study of phenomena involving humans (Mota, 2005; 2010). The science of human development and hospital-health psychology followed the same path as science up to that point. The knowledge produced by these areas became increasingly isolated from other disciplines, decontextualized and divorced from reality (Cerqueira-Silva, Dessen, \& Costa Junior, 2011). In light of this crisis, there was a need to integrate knowledge in order to help understand the phenomena of life and its complexity. The contributions of complex systematic thinking resonate in the production of the theoretical models of human development, which consider the complex network of the life cycle. This complex holistic view of human development is evident in the sociohistorical approach of Lev Vygotsky and the ecological perspective of Urie Brofrenbrenner (Carvalho-Barreto, 2016; Mota, 2005). Moreover, systematic thinking has an impact on research and the techniques used in hospital-health psychology, the latter moving away from a mere psychologism of the health-disease process and evolving to total understanding of the disease phenomenon, hospitalization, prevention and health promotion, in a notably biopsychosocial perspective (More, Crepaldi, Gonçalves, \& Menezes, 2009).

Currently, several theoretical explanations coexist, distinguished by their dynamic and complex nature and constant interaction between biological, psychosocial and cultural factors. This scenario also requires the production of knowledge that views the phenomenon in a complex manner, demanding an interdisciplinary approach to produce this knowledge.

Interdisciplinarity ${ }^{1}$ can be characterized as intense sharing of knowledge between specialists and the degree of real integration of disciplines within a same project (Japiassu, 1976). Acknowledging the interdisciplinary nature of fields such as Human Development and Hospital-Health Psychology has prompted reflections on the limitations of categorizing and describing phenomena common to these fields, and favored the search for a dialogic, integrated, pluralistic, complex and multifaceted perspective of these phenomena (Cerqueira-Silva et al., 2011). Introducing interdisciplinarity into these two fields of knowledge resulted in methodological reformulations of production, expanding methodological frontiers. This resulted in the use of research methods in line with the complexity of the phenomena studied. As such, systemic, longitudinal, transcultural, mixed and multimethod studies emerged in both sciences.

\section{Research into the Contemporary Psychology and Health-disease interface}

Given the scenario of transformations described earlier, there is a need for research methods that consider the complexity of the phenomena studied. As mentioned, these methods are strategies that learn the complexity of the phenomena of interest, such as longitudinal, transcultural, mixed and multimethod studies.

The first method, observational longitudinal studies, involves identifying a specific phenomenon of interest and monitoring it for a predetermined period to identify changes, transformations or stabilities during this time. Unlike cross-sectional observational studies, which provide an instant picture of the topic of interest, the researcher can opt for two methodologies, but neither requires a time period to monitor the phenomenon of interest (Creswell, 2010; Vizzotto \& CressoniGomes, 2005). There are two types of longitudinal study: 
prospective or retrospective cohorts, which follow the evolution of a particular characteristic or phenomenon in the population under study. The latter typically uses documental material in its analysis (Vizzotto \& CressoniGomes, 2005). Transcultural studies compare the occurrence of a certain manifestation in different cultures, in order to understand how these phenomena are socioculturally influenced. In addition to using the same instrument in data collection, or identifying psychosocial similarities and differences between subjects from different cultures, transcultural studies require researchers to determine the cultural influence (or not) on the variables of the phenomenon studied (Gomes et al., 2018).

Finally, mixed and multimethod studies simultaneously or sequentially combine quantitative and qualitative approaches in a same investigation. These designs are a growing trend in studies on the hospital-health psychology because they make it possible to research the complex phenomena that permeate the area (Creswell, 2010; Paranhos, Figueiredo Filho, Rocha, Silva Júnior, \& Freitas, 2016; Santos et al., 2017).

According to Creswell (2010), quantitative and qualitative techniques exhibit potentials and limitations. They are generally applied with definitive objectives. However, the combining these methods allows researcher to extract the best from each one in order to answer a specific question regarding a particular object of study.

Paranhos et al. (2016) contends that despite ample dissemination in the literature, applying complex research methods remains incipient, due more to lack of specific training in implementing systemic complex methods than ontological or epistemological limitations in the scientific community.

In the current scenario of Brazilian research, based on the Directory of Research Groups in Brazil (DGP-CNPq), the terms psychology and human development identify two research groups that intersect the field of health and human development, one located in the South of the country, the Psychology of Health and Human Development group (KOAN) of the Federal University of Santa Catarina (UFSC), and one in the Northeast, the Group of Psychology and Health Studies (GEPS) of the Federal University of Rio Grande do Norte (UFRN).

The latter group (GEPS), which emerged in 2000 in the Psychology Department of the Federal University of Rio Grande do Norte, was created to promote research and extension activities in the field of Hospital-Health Psychology, contributing to the scientific and professional enhancement of students and researchers, with human development and interdisciplinarity as the background to their actions. The group currently consists of psychologists, nurses and physiotherapists who aim to apply complex methods, such as quantitative and qualitative designs, either simultaneously or sequentially.

\section{Final considerations}

We revisited the history of two fields of psychology as a science and profession: hospital-health psychology and human development. This trajectory demonstrated that these areas overlap in terms of the methods used to construct knowledge and conduct research. During their unique trajectories, both were influenced by the introduction of complex thinking, as well as interdisciplinarity into human science studies.

This scenario corroborates towards combining psychological research with other sciences in investigations, medicine, nursing, physiotherapy and other health sciences, without losing sight of the specificities and particularities that each field contributes to understanding the phenomenon under study. However, despite the different epidemiological, methodological and paradigm shifts that have occurred in human sciences, much remains to be done to effectively implement a knowledge construction and research framework that addresses the complexity of the health-disease process.

\section{References}

Alves, R., Santos, G., Ferreira, P., Costa, A., \& Costa, E. (2017). Atualidades sobre a psicologia da saúde e a realidade Brasileira. Psicologia, Saúde \& Doenças, 18(2), 545-555. doi: 10.15309/17psd180221

Azevedo, A. V.S., \& Crepaldi, M. A. (2016). A Psicologia no hospital geral: aspectos históricos, conceituais e práticos. Estudos de Psicologia, 33(4), 573-585. doi: 10.1590/1982-02752016000400002

Biagi-Borges, A. L., Tonon, L., Scorsolini-Comin, F., \& Peres, R. S. (2015). Pesquisa em psicologia da saúde: avaliação da produção de um programa de pós-graduação. Gerais: Revista Interinstitucional de Psicologia, 8(1), 143-155. Retrieved from http://pepsic.bvsalud.org/ scielo.php?script=sci_arttext\&pid=S1983-82202015000100011\&Ing= en\&tlng=pt

Carvalho-Barreto, A. (2016). Paradigma sistêmico no desenvolvimento humano e familiar: a Teoria Bioecológica de Urie Bronfenbrenner. Psicologia em Revista, 22(2), 275-293. doi: 10.5752/P.1678-9523.2016V22N2P275

Carvalho, D. B., Souza, L. M. R., Rosa, L. S., \& Gomes, M. L. C. (2011). Como se escreve, no Brasil, a História da Psicologia no contexto hospitalar? Estudos e Pesquisas em Psicologia, 11(3), 1005-1026. Retrieved from http://pepsic.bvsalud.org/scielo. php?script=sci_arttext\&pid=S1808-42812011000300016\&lng= pt\&ting=pt

Castro, E.K., \& Bornholdt, E.(2004).Psicologia da saúdexpsicologia hospitalar: definições e possibilidades de inserção profissional. Psicologia: Ciência e Profissão, 24(3), 48-57. Retrieved from http://pepsic.bvsalud.org/ scielo.php?script=sci_arttext\&pid=S1414-98932004000300007\&lng=p t\&tlng=pt 
Cerqueira-Silva, S., Dessen, M. A., \& Costa Junior, A. L. (2011). As contribuições da ciência do desenvolvimento para a psicologia da saúde. Ciência \& Saúde Coletiva, 16(suppl. 1), 1599-1609. doi: 10.1590/ S1413-81232011000700096

Creswell, J. W. (2010). Projeto de pesquisa: métodos qualitativo, quantitativo e misto ( $3^{\text {rd }}$. ed.) Porto Alegre: Artmed.

Gomes, L. B., Bossardi, C. N., Bolze, S. D. A., Bigras, M., Paquette, D., Crepaldi, M. A., \& Vieira, M. L. (2018). Pesquisas transculturais em psicologia do desenvolvimento: considerações teóricometodológicas. Arquivos Brasileiros de Psicologia, 70(1), 260-275. Retrieved from http://pepsic.bvsalud.org/scielo. php?script=sci_arttext\&pid=S1809-52672018000100018\&lng= pt\&tlng=pt

Japiassu, H. (1976). Interdisciplinaridade e patologia do saber. Rio de Janeiro: IMAGO.

Marinho-Araújo, C.M. (2006). A ciência do desenvolvimento humano: para além de uma Psicologia do Desenvolvimento. Psicologia Escolar e Educacional, 10(1), 135-136. doi: 10.1590/S1413-85572006000100013

More, C. L. O. O., Crepaldi, M. A., Gonçalves, J. R., \& Menezes, M. (2009). Contribuições do pensamento sistêmico à prática do psicólogo no contexto hospitalar. Psicologia em Estudo, 14(3), 465-473. doi: 10.1590/S1413-73722009000300007

Mota, M.E. (2005).Psicologia do desenvolvimento: uma perspectiva histórica. Temas em Psicologia, 13(2), 105-111. Retrieved from http://pepsic. bvsalud.org/scielo.php?script=sci_arttext\&pid=S1413-389X200500 0200003\&lng=pt\&tIng=pt

Mota, M. E. (2010). Metodologia de Pesquisa em Desenvolvimento Humano: velhas questões revisitadas. Psicologia em Pesquisa, 4(2), 144-149. Retrieved from http://pepsic.bvsalud.org/scielo. php?script=sci_arttext\&pid=S1982-12472010000200007\&lng= pt\&tlng=pt
Neri, A. L. (2004). Contribuições da psicologia ao estudo e à intervenção no campo da velhice. Revista Brasileira de Ciências do Envelhecimento Humano, 1(1), 69-80. Doi: 10.5335/rbceh.2012.46

Oliveira, A. (2011). Psicologia da saúde e o paradigma biopsicossocial: um ensaio epistemológico. Revista de enfermagem UFPE on line, 5(9), 2309-2316. doi: 10.5205/reuol.1262-12560-1-LE.0509201131

Paranhos, R. F., Figueiredo Filho, D. B., Rocha, E. C., Silva Júnior, J. A., \& Freitas, D. (2016). Uma introdução aos métodos mistos. Sociologias, 18(42), 384-411. doi: 10.1590/15174522-018004221

Reis, J. A. R., Machado, M. A. R., Ferrari, S., Santos, N. O., Bentes, A. Q., \& Lucia, M. C. S. (2016). Prática e inserção do psicólogo em instituições hospitalares no Brasil: revisão da literatura. Psicologia Hospitalar, 14(1), 2-26. Retrieved from http://pepsic.bvsalud.org/ scielo.php?script=sci_arttext\&pid=S1677-74092016000100002\&lng= pt\&tlng=pt

Santos, J. L. G., Erdmann, A. L., Meirelles, B. H. S., Lanzoni, G. M. M., Cunha, V.P., \& Ross, R. (2017). Integração entre Dados Quantitativos e Qualitativos em uma Pesquisa de Métodos Mistos. Texto \& Contexto - Enfermagem, 26(3), 1-9. doi: 10.1590/0104-07072017001590016

Silva, L., Tonetto, A., \& Gomes, W. (2006). Prática psicológica em hospitais: adequações ou inovações? Contribuições históricas. Boletim Academia Paulista de Psicologia, XXVI(3), 24-37.

Vizzotto, M. M., \& Cressoni-Gomes, R. (2005). A Metodologia em ciências da saúde. Mudanças - Psicologia da Saúde, 13(1), 233-243. doi: 10.15603/2176-1019/mud.v13n1p233-243

Yamamoto, O. H., Trindade, L. C. B. O., \& Oliveira, I. F. (2002). O psicólogo em hospitais no Rio Grande do Norte. Psicologia USP, 13(1), 217-246. doi: 10.1590/S0103-65642002000100011

1. For a more in-depth definition of interdisciplinarity and its distinction from other concepts, we suggest reading the following articles: "Interdisciplinaridade: para além da filosofia do sujeito" ("Interdisciplinarity: beyond the philosophy of the subject"), editor Vozes, and "Inter ou transdisciplinaridade: da fragmentação disciplinar ao novo diálogo entre os saberes" (Inter or transdisciplinarity: from disciplinary fragmentation to a new dialog between the fields of knowledge"), editor Paulus.

Rodrigo da Silva Maia, doutor em psicologia pela Universidade Federal do Rio Grande do Norte, é docente na Universidade Federal do Ceará. Endereço para correspondência: Rua Nogueira Acioli, 1769. Joaquim Távora, Fortaleza, Ceará, Brasil. CEP: 60110-515. Telefone: (84) 99980-0721 ou (88) 3695-4641/3695-4639/3695-4619. E-mail: rodrigo_maia89@yahoo.com.br

Thaiza Teixeira Xavier Nobre, doutora em ciências da saúde pela Universidade Federal do Rio Grande do Norte, é docente na Universidade Federal do Rio Grande do Norte. E-mail: thaizaxnobre@gmail.com

Gilson de Vasconcelos Torres, doutor em enfermagem fundamental pela Universidade de São Paulo (USP), pós-doutor em enfermagem pela Universidade de Évora (UE), Portugal, é professor titular na Universidade Federal do Rio Grande do Norte. E-mail: gilsonvtorres@hotmail.com

Eulália Maria Chaves Maia, doutora em psicologia clínica pela

Universidade de São Paulo, é professor titular na Universidade Federal do Rio Grande do Norte. E-mail: eulalia.maia@yahoo.com.br

Received in 10.april.19 Revised in 07.july.19

Accepted in 10.dec.19 